\title{
Is agriculture connected with stunting in Indonesian children living in a rice surplus area? A case study in Demak regency, central Java
}

\author{
Ratna Chrismiari Purwestri ${ }^{1,2}$ - Loretta Renz ${ }^{1,3}$. Nia Novita Wirawan ${ }^{2}$. \\ Ignasius Radix A. P. Jati ${ }^{4}$ Ilmia Fahmi ${ }^{2}$ Hans Konrad Biesalski ${ }^{1,5}$
}

Received: 2 May 2016 / Accepted: 23 November 2016

(C) Springer Science+Business Media Dordrecht and International Society for Plant Pathology 2017

\begin{abstract}
Central Java province plays the main role in the production of food for national stocks in Indonesia, in which Demak is one of the 35 Regencies. Demak Regency had the sixth highest rice productivity in 2013, but at the same time, the seventh highest percentage of child malnutrition. This paradox between high rice productivity and low nutritional status of children triggered an interest in analyzing the correlations between agricultural production of households in the Demak Regency and the prevalence of stunting of children underfive. In December 2014 to February 2015, a cross-sectional survey was carried out in three sub-districts in Demak (Karanganyar, Dempet and Gajah) having the highest rice production and at the same time poor nutritional status of under-five children. The oldest under-five children from farmer family backgrounds were selected. Data on general characteristics, anthropometry of the children, as well as household socio-economics, including agricultural characteristics were obtained. Of the 335 children, $31.9 \%$ of them were stunted. A higher proportion of households that grew rice solely or mainly for own consumption (62.4\%) and had significantly
\end{abstract}

Ratna Chrismiari Purwestri

rc.purwestri@uni-hohenheim.de; purwestri@yahoo.com

1 Institute for Biological Chemistry and Nutrition Science (140), University of Hohenheim, Garbenstrasse 30, 70599 Stuttgart, Germany

2 Faculty of Medicine, Nutrition Department, University of Brawijaya, Malang, Indonesia

3 Organic Agriculture and Food Systems, University of Hohenheim, Stuttgart, Germany

4 Department of Food Technology, Widya Mandala Surabaya Catholic University, Surabaya, Indonesia

5 Food Security Center, University of Hohenheim, Stuttgart, Germany smaller sized rice-fields $(p=0.041)$ had stunted rather than non-stunted children. In total, rice production, farm income and agriculture diversity of families with non-stunted children were not significantly different from those of stunted children. However, yearly expenditure for improving family health and environmental conditions were significantly higher among non-stunted than stunted children $(p=0.044)$. Family decisions about what to spend money on also seemed to influence the nutritional status of the children, rather than nutritional diversity or revenue from agriculture itself. Therefore, improvement of agricultural production and diversity should be accompanied by education on household expenditure.

Keywords Rice production - Agriculture diversity · Expenditure $\cdot$ Income $\cdot$ Stunting

\section{Introduction}

In agricultural societies, farming activities depend on wellnourished and healthy people to work in this labour-intensive sector while, on the other hand, people depend on agriculture to receive food with adequate nutrients (Fan et al. 2012). Kennedy and Bouis (1993) and Haddad (2000) found a strong link between agriculture and the nutritional status of farmers and their family members. More recently, Kumar et al. (2015) also found a strong positive impact of the diversity of agricultural production on height-for-age Z-scores (HAZ) of children above two years of age in Zambia. On the contrary, a study among Kenyan children showed no correlation between agriculture diversity and stunted children (M'Kaibi et al. 2016).

The first 1000 days of life that include the days from the beginning of pregnancy until the end of a child's second year of life, are of high importance for the development of the foetus and the child. When a child suffers from malnutrition 
during the first 1000 days, stunting can occur and the child has no chance to catch up with its development afterwards (Black et al. 2008; Victora et al. 2008, 2010). Grantham-McGregor et al. (2007) has stated that stunted children have underdeveloped socio-emotional and cognitive skills and underdeveloped motor abilities. The underdeveloped cognitive skills lead to lower school performance and a decrease in working productivity in later life (Martorell 1999, 2010a, b; Dewey and Begum 2011). Gross et al. (1996) have also shown that the growth rate of a child starts to decrease from the age of six months when a child's complementary feeding becomes necessary. In this transitory period, the nutritional needs of the child often cannot be met as complementary feeding is inadequate. Seth et al. (2011) found that stunting starts mostly at the age of six months and reaches its highest level between 18 and 24 months. The consumption of a low quality diet (low in macro and micronutrients) over a long time in conjunction with frequent infections and adverse environmental circumstances leads to stunting (Rosado 1999; Stephensen 1999; Black et al. 2008; Semba et al. 2008).

In Indonesia, rice is the staple of most dishes in the typical local diet, comprising $60 \%$ of the diet, and is consumed at breakfast, lunch and dinner (Jati et al. 2012; Purwestri et al. 2013). Rice paddy production is promoted because the demand for rice is high. In 2013, Central Java was the second highest rice productivity area (Central Java Statistics Bureau 2014). However, this high rice productivity is in contrast to the nutritional status of children living in the area. In the same year, the Indonesian Ministry of Health (2013) reported that prevalence of stunted children (HAZ below -2 SD of the reference population) in Demak was above 30\%, indicating an alarming incidence of chronic malnutrition in the area. Therefore, the aim of this study was to investigate the correlation of agricultural factors with the nutritional status of children below five years old in a rice surplus area but having high prevalence of stunted children.

\section{Methods}

A cross sectional survey was conducted between December 2014 and February 2015 in Demak Regency, Central Java, Indonesia. As compared to the other 35 Regencies in Central Java, Demak Regency had the sixth highest rice productivity in 2013 of $6117 \mathrm{~kg}$ per hectare and at the same time the seventh highest percentage of child malnutrition (indicated by weight-for-age Z-score <-2SD) of $9.44 \%$ in 2012 (Central Java Statistics Bureau 2014; Central Java Public Health Office 2012). In 2013 the Indonesian Ministry of Health also reported that prevalence of stunted children (height-for-age z-score (HAZ) below $-2 \mathrm{SD}$ of the reference population) in Central Java was above 30\% (Ministry of Health 2013). Nutritional status based on HAZ-score of the
Indonesian children at province level is usually reported by the Indonesian Ministry of Health as part of a regular national health and nutrition survey. Height of the children was not commonly measured during a monthly growth monitoring program in the Integrated Health Post (in the local language called Pos Pelayanan Terpadu) at village level carried out by voluntary workers. Therefore, the Central Java province only reported the nutritional status based on the WAZ score of the children. In Demak, Karanganyar, Dempet, and Gajah sub-districts were also chosen because these sub-districts had high rice productivity and poor nutritional status of under-five children. In total, eight villages in Karanganyar, seven villages in Dempet and one village in Gajah were categorized as rice surplus areas and were then chosen as sites for data collection.

Subjects of this study were the oldest non-exclusively breastfed children (aged between 6 and 60 months) living with at least one household member who was occupied as a farmer. Stunting started to become apparent mostly at the age of six months and reached its highest level between 18 and 24 months, when exclusive breastfeeding is stopped and the intake of complementary food is often inadequate (Gross et al. 1996; Seth et al. 2011). Therefore, the oldest under five children within the family were chosen in order to capture as many stunted children as possible. Farmers with land, tenant farmers, farm workers, sharecroppers or livestock raisers were all included in the definition of farmer.

Numbers of children per sub-district was proportionally determined, based on the lists of potentially eligible children in the selected villages collected from village midwives or health/nutrition voluntary workers. Simple random sampling was applied to choose the eligible children from the lists.

A structured and quantitative questionnaire was used for data collection. Prior to the onset of the study, the questionnaire was pretested at the University of Hohenheim, Germany and the University of Brawijaya, Malang-Indonesia, and it was also pretested in Demak. During data collection, mothers of eligible children were interviewed at home and asked about the child's general, family and socio-demographic characteristics (such as number of children in the household, household size and ownership, rice-field size), and items on which money was spent. Fathers were asked about agriculture related factors including agricultural production and diversity. Farm income was derived from the total revenue from farming activities (namely rice, other crops or livestock sales) within the last one year. Data on previous year household expenditure was collected and presented based on monthly- (regular-) and yearly- (non-regular-) expenditure. Heights of the children were measured using a height/length board (for above/below two years old) and their weights were determined using a SECA 201 scale. All measurements were carried out twice, unless a third measurement was needed for confirmation; the average of the two measurements was used for the analysis. 
In addition, three heads of the village and three farmers were interviewed in-depth in order to ascertain the local agriculture situation, especially regarding the local term of landsize (one 'Bau') and typical yearly production. Qualitative data were recorded, noted and transcribed for further analysis.

\section{Sample size}

A minimum sample size of 330 children was determined for a cross-sectional study in the area having a stunting prevalence of $31.1 \%$ in Central Java (Ministry of Health 2013) with a confidence level of $95 \%$ and a power of 0.8 . In addition, for detecting proportion differences between groups of stunted vs. non-stunted children, a minimum of 95 children per group was calculated (Lwanga and Lemeshow 1991). The final sample size of this study was 335 eligible children.

\section{Data analysis}

An analysis was performed, testing the relationship of family demographic characteristics, household expenditure and agricultural production characteristics and revenue of the 335 households based on HAZ-scores of the children.

Data were checked for conforming to a normal distribution using QQ-plots of normality. For normally distributed data, differences in means were tested with the Independent T-test test, while for the non-normally distributed data the MannWhitney U-test was used. Group comparisons were analysed using a Chi's square or Fischer exact test.

Statistical analysis was performed using IBM SPSS Statistics Version 22. Anthropometric data were transformed to Z-scores using Emergency Nutrition Assessment version 2011 (ENA for SMART). Two groups of children were categorized based on HAZ-scores; below -2SD was defined as stunted, while HAZ-scores above -2 SD were considered non-stunted.

\section{Results}

Table 1 shows the characteristics of the 335 children aged between 6 and 60 months and their families. Of 335 children from farmer-family backgrounds, $31.9 \%$ of them were stunted $(n=107)$ and $1.8 \%$ of the total children had HAZ $\geq 3$ SD. Their main socio-economic and agriculture characteristics were similar to the children with HAZ-score $\geq-2$ to $<+2 \mathrm{SD}$, who were classified as non-stunted children $(n=228)$. Stunted children were significantly older, lighter and shorter than nonstunted children. The proportion of boys and girls in both stunted vs non-stunted children was not significantly different. Both groups of children were from similar socio-demographic backgrounds as indicated by household size and type, housing ownership, parental occupation, and educational level. Among stunted children, $8.4 \%$ and $1.9 \%$ of them had WHZ- scores below $-2 \mathrm{SD}$ and over $+2 \mathrm{SD}$, respectively. The results were similar to $11 \%$ and $1.8 \%$ of non-stunted children who were wasted and overweight, respectively.

At the time of the survey, a total of $19.7 \%$ (66) of the 335 households had no agricultural production in the previous year. However, all respondents reported that at least one of their family members had earned some revenue from agricultural activities as farm workers. The other $80.3 \%$ (269) of households had between one and four types of agricultural production (crops and/or livestock). As seen in Fig. 1, both non-stunted and stunted children groups were from similar agriculture situations as demonstrated by the crops grown. Rice was the main product in this study area, followed by mungbean, onion, different kinds of fruits, and garlic. In total, $76.7 \%$ of households (257) cultivated rice on fields between $50 \mathrm{~m}^{2}$ and $21000 \mathrm{~m}^{2}$ in size, in which 178 and 79 of them were the households with non-stunted and stunted children, respectively. The farmers harvested rice between one and three times per year and produced between 10 and 24,000 $\mathrm{kg}$ of rice per harvest. Of the households that cultivated rice, the purposes for producing rice (for their own consumption, sale, seeding, and other uses) was not significantly different between families with non-stunted and stunted children (Table 2). However, it is important to note that $74.7 \%$ of families with stunted children produced more rice for their own consumption (median: $500 \mathrm{~kg} /$ year) as compared to $62.4 \%$ of families having non-stunted children (median: $370 \mathrm{~kg} /$ year). During the time of data collection, households received a median price of $€ 23$ or Rp 350,000 per $100 \mathrm{~kg}$ of unhulled rice. The households with non-stunted children had higher median revenue from selling the rice production $(€ 586.6)$ than that of households with stunted children $(€ 420.0)$ (Table 2). It was also found that $15.2 \%$ and $16.3 \%$ of the families having non-stunted and stunted children, respectively, consumed all their rice production.

Unlike rice production, mungbeans were mostly intended for sale. Mungbeans are cultivated once a year, during the dry seasons, when farmers do not plant rice. The selling price of mungbeans typically fluctuates and households with nonstunted children had slightly less revenue than those with stunted children. During the previous year, farmers received a median price of $€ 82.0$ or Rp $1,250,000$ per $100 \mathrm{~kg}$. Of 156 farmers who grew mungbeans, $64.1 \%$ of them belonged to the non-stunted group and received a median price of $€ 137.0$ as revenue (Table 2). Moreover, 3.6\% of the households raised chickens for meat production, and only one household raised quail for egg production and one household had goats.

In total, families with non-stunted children earned slightly higher total farm income ( $€ 704.1)$ compared to the families with stunted children $(€ 590.6)$.

Table 3 shows the household expenditures in Euro $(€)$. Monthly expenditure on education, social activities, food, agriculture equipment, and savings were not significantly 
Table 1 Characteristics of the children and selected parental socio-demographic ${ }^{\mathrm{a}}$

\begin{tabular}{|c|c|c|c|}
\hline General characteristics $(N=335)$ & $\begin{array}{l}\text { Non-stunted children } \\
(n=228)\end{array}$ & $\begin{array}{l}\text { Stunted children } \\
(n=107)\end{array}$ & $p$ value $^{\mathrm{c}}$ \\
\hline \multicolumn{4}{|l|}{ Children } \\
\hline Number of children studied (n) & 228 & 107 & \\
\hline Female & $43.9(100)$ & $53.3(57)$ & 0.108 \\
\hline Age of children (months) & $29.9 \pm 15.3$ & $34.3 \pm 13.0$ & 0.008 \\
\hline$->6$ to 24 months & $39.0(89)$ & $29.9(32)$ & 0.105 \\
\hline$->24$ months & $61.0(139)$ & $70.1(75)$ & \\
\hline Weight $(\mathrm{kg})$ & $11.3 \pm 2.9$ & $10.6 \pm 2.1$ & 0.003 \\
\hline Height (cm) & $86.5 \pm 10.7$ & $83.4 \pm 7.9$ & 0.007 \\
\hline Prevalence of breastfeeding children & $62.3(142)$ & $59.8(64)$ & 0.665 \\
\hline \multicolumn{4}{|l|}{ Selected parental socio-demographic characteristics } \\
\hline \multicolumn{4}{|l|}{ Age (years) } \\
\hline - Father ${ }^{\mathrm{b}}$ & $36.3 \pm 7.2$ & $36.4 \pm 7.0$ & 0.831 \\
\hline - Mother & $31.0 \pm 6.5$ & $31.5 \pm 6.2$ & 0.567 \\
\hline \multicolumn{4}{|l|}{ Education level: above senior high school } \\
\hline - Father ${ }^{\mathrm{b}}$ & $14.9(34)$ & $13.1(14)$ & 0.656 \\
\hline - Mother & $16.2(37)$ & $16.8(18)$ & 0.891 \\
\hline \multicolumn{4}{|c|}{ Main occupation: Farmer [farmer, tenant farmer, farm worker, sharecropper] } \\
\hline - Father ${ }^{\mathrm{b}}$ & $81.6(186)$ & $81.3(87)$ & 0.953 \\
\hline - Mother & $15.8(36)$ & $14.0(15)$ & 0.674 \\
\hline Mother had a job & $42.1(96)$ & $32.7(35)$ & 0.100 \\
\hline Household size ( $>4$ persons) & $45.2(103)$ & $38.3(41)$ & 0.237 \\
\hline Extended family & $26.3(60)$ & $19.6(21)$ & 0.182 \\
\hline \multicolumn{4}{|l|}{ Housing condition } \\
\hline - owned house & $62.7(143)$ & $65.4(70)$ & 0.725 \\
\hline - parent's house & $25.4(58)$ & $21.5(23)$ & \\
\hline - patrimony/other family's or other's house & $11.8(228)$ & $13.1(14)$ & \\
\hline
\end{tabular}

${ }^{\mathrm{a}}$ Data are presented as $\%(\mathrm{n})$, or mean $\pm \mathrm{SD}$,

${ }^{b}$ Two fathers had no information,

${ }^{\mathrm{c}}$ Group comparisons were analysed using a Chi's square test (categorical data) or Independent T test (continuous and normally distributed data)

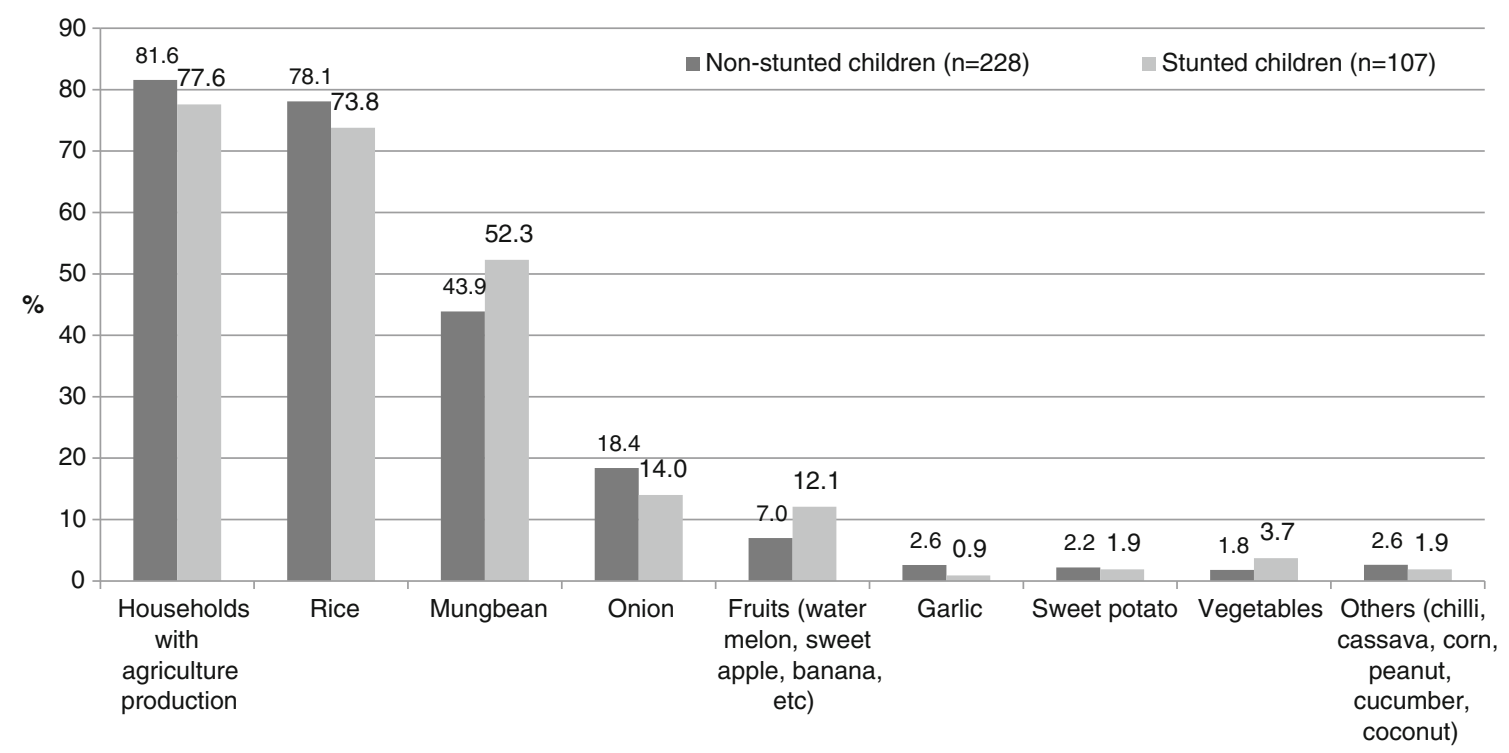

Fig. 1 Main crops grown in the field by households with non-stunted and stunted children 
Table 2 Selected characteristics of agriculture-related factors produced by the respondents ${ }^{\mathrm{a}}$

\begin{tabular}{|c|c|c|c|}
\hline Characteristics & Non-stunted children & Stunted children & $p$ value $^{\mathrm{e}}$ \\
\hline Rice (n) & 178 & 79 & 0.408 \\
\hline Field size $\left(\mathrm{m}^{2}\right)$ & $3500.0(1750.0 ; 5250.0)$ & $1750.0(1750.0 ; 3500.0)$ & 0.041 \\
\hline \multicolumn{4}{|l|}{ Purposes } \\
\hline - for own consumption & $62.4(111)$ & $74.7(59)$ & 0.054 \\
\hline - for sale & 83.7 (149) & $84.8(67)$ & 0.824 \\
\hline - for seeding & $32.6(58)$ & $31.6(25)$ & 0.882 \\
\hline - for other uses ${ }^{b}$ & $15.7(28)$ & $13.9(11)$ & 0.710 \\
\hline Production (in kg/year) & $2225.0(1237.0 ; 5600.0)$ & $2000.0(1500.0 ; 4500.0)$ & 0.288 \\
\hline - for own consumption & $365.0(0.0 ; 907.8)$ & $500.0(0.0 ; 990.0)$ & 0.351 \\
\hline - for sale & $1860.0(500.0 ; 5100.0)$ & $1560.0(470.0 ; 3360.0)$ & 0.248 \\
\hline - for seeding & $0.0(0.0 ; 20.0)$ & $0.0(0.0 ; 20.0)$ & 0.636 \\
\hline - for other uses ${ }^{\mathrm{b}}$ & $0.0(0.0 ; 0.0)$ & $0.0(0.0 ; 0.0)$ & 0.565 \\
\hline Revenue from selling rice production (n) & 149 & 67 & 0.627 \\
\hline - Total $\left(€ /\right.$ year $\left.^{\mathrm{c}}\right)$ & $586.6(229.7 ; 1345.1)$ & $420.0(234.0 ; 881.9)$ & 0.367 \\
\hline Mungbean (n) & 100 & 56 & 0.160 \\
\hline Field size $\left(\mathrm{m}^{2}\right)$ & $2125.0(1750.0 ; 3500.0)$ & $1750.0(1750.0 ; 3500.0)$ & 0.219 \\
\hline \multicolumn{4}{|l|}{ Purposes } \\
\hline - for own consumption & $0.08(8)$ & $0.09(5)$ & 1.000 \\
\hline - for sale & $100.0(100)$ & $54.0(96.4)$ & 0.127 \\
\hline - for seeding & $0.02(2)$ & $1.8(1)$ & 0.166 \\
\hline - for other uses & $0.02(2)$ & $1.8(1)$ & 0.166 \\
\hline Production (in kg/year) & $200.0(100.0 ; 352.0)$ & $200.0(100.0 ; 310.0)$ & 0.874 \\
\hline - for sale & $197.5(92.0 ; 337.5)$ & $194.0(95.3 ; 300.0)$ & 0.250 \\
\hline - for seeding & $0.0(0.0 ; 10)$ & $0.0(0.0 ; 10)$ & 0.873 \\
\hline Revenue from selling bean production & 100 & 54 & 0.290 \\
\hline - Total (€/year) & $137.0(65.6 ; 308.1)$ & $158.3(67.6 ; 266.7)$ & 0.794 \\
\hline $\begin{array}{l}\text { Farmers with income from agriculture } \\
\text { activities (n) }\end{array}$ & 222 & 107 & 0.182 \\
\hline \multicolumn{4}{|l|}{ Revenue from total agriculture activities ${ }^{\mathrm{d}}$} \\
\hline - Total (€/year) & $704.1(238.5 ; 1930.8)$ & $590.6(236.2 ; 1273.0)$ & 0.581 \\
\hline
\end{tabular}

${ }^{\text {a }}$ Data are presented as \% (n), or median (25th;75th percentiles);

${ }^{\mathrm{b}}$ Mostly for social gathering activities;

${ }^{\mathrm{c}}$ Revenue was calculated only for farmers who sold the rice production, exchange rate: $1 €=\mathrm{Rp} 15,240$;

${ }^{\mathrm{d}}$ Total revenue derived from calculation of all crops and livestock production and farmworker wages within the last 1 year;

${ }^{\mathrm{e}}$ Data was analysed using Chi square or Fischer exact test (for categorical data) and Mann-Whitney test (for not normally continuous variables) different between the two groups. The highest mean expenditures were the non-routine expenditures in the last year for improvement in environmental living conditions and family health with $€ 254.3$ (38.1; 787.425 th and 75 th percentiles) from households having non-stunted children, a figure significantly higher than that of $€ 150.9$ (2.6; 524.9 25 th and 75 th percentiles) from households with stunted children $(p=0.044)$.

Based on the results of in-depth interviews with farmers and heads of villages, it was found that despite the high rice production, many of the farmers in the study area rented their farm land. The rental cost of one Bau of land (one Bau is about 6000 to $7500 \mathrm{~m}^{2}$ ) varied between twelve and fifteen million rupiahs ( $\pm € 787$ to $€ 984$ ) per rice planting season. It was estimated that the production cost of a rice plantation per season was about three to five million rupiahs $( \pm € 197$ to $€ 328)$ per Bau. During data collection, the farmers experienced a lean season. Rice seeds had just been planted in December and the farmers needed to wait until March for harvesting.

\section{Discussion}

The elevation of Demak Regency varies from $0 \mathrm{~m}$ to $100 \mathrm{~m}$ above sea level. The soil texture in this Regency varies from 
Table 3 Households' expenditures $(€)^{\mathrm{a}}$

\begin{tabular}{|c|c|c|c|}
\hline Expenditures in the last month & $\begin{array}{l}\text { Non-stunted children } \\
(n=228)\end{array}$ & $\begin{array}{l}\text { Stunted children } \\
(n=107)\end{array}$ & $p$ value $^{\mathrm{c}}$ \\
\hline Transportation & $5.6(2.6 ; 12.8)$ & $6.7(2.6 ; 9.8)$ & 0.834 \\
\hline Cigarettes & $8.9(0.0 ; 19.7)$ & $8.9(0.0 ; 17.7)$ & 0.625 \\
\hline Household & $10.9(7.2 ; 17.4)$ & $9.5(7.0 ; 19.0)$ & 0.735 \\
\hline Food & $47.8(35.2 ; 61.7)$ & $45.8(29.5 ; 60.9)$ & 0.397 \\
\hline Total routine expenditures & $113.5(87.7 ; 151.3)$ & $109.5(79.6 ; 144.0)$ & 0.321 \\
\hline \multicolumn{4}{|l|}{ Non-routine expenditures in the last year } \\
\hline Education & $6.6(0.0 ; 16.7)$ & $7.8(0.0 ; 32.8)$ & 0.111 \\
\hline Cultural activities & $1.2(0.0 ; 59.1)$ & $0.0(0.0 ; 39.3)$ & 0.610 \\
\hline Family health and environmental condition ${ }^{\mathrm{b}}$ & $254.3(38.1 ; 787.4)$ & $150.9(2.6 ; 524.9)$ & 0.044 \\
\hline
\end{tabular}

finely ground texture to moderate soil texture (clay) and therefore is considered to have a good level of fertility. Sustainability of the water supply is not only dependent on water from the surrounding rivers, but is also due to irrigation from a water reservoir, including the Kedungombo Reservoir, making it possible for the land to remain productive during the dry season. Thus, it is not surprising that the livelihood of most of the population in Demak relies on the agricultural sector. As a result, Demak is known as the national granary because it is one of the largest suppliers of rice in Central Java.

Rice production for families with non-stunted children was higher than their stunted children counterparts. In total, yearly brutto revenue from rice sales was about $€ 420.0$ ( $€ 35.0$ / month) among households with stunted children and was lower than that from families with non-stunted children ( $€ 586.6$ or $€ 48.9 /$ month: Table 2). The yearly brutto revenue is defined as the total income received by farmers before deduction of all cash expenses, e.g. pesticides, fertilizers and wages. Revenues from rice, mungbeans, and all agricultural production in the study area (Table 2) were significantly lower than the 2014 monthly regional minimum wage in Central Java by $\mathrm{Rp}$ 1280000 or $€ 84.0 /$ month or $€ 1008 /$ year. In total, slightly higher proportion of the households with stunted children $(67.3 \%)$ received income less than the monthly minimum wage in contrast to the $59.5 \%$ of families with non-stunted children. We presumed that a low revenue from the agriculture sector was likely to be the main cause of the high prevalence of stunted children in the area. Although not statistically significantly different, the total farm income difference of $€ 113.5$ (Table 2) seemed to be important for households with nonstunted stunted children for maintaining their health and nutrition. Households that consumed more of their rice production were found to have stunted children. In this area, farmers who produced rice only and mostly for own consumption, had or rented significantly smaller plots and produced limited rice. Since these farmers did not have income from selling rice, their predicted income was usually lower (even zero) than that of farmers who sold rice. Stunted children came from households with significantly smaller land areas for rice cultivation than those of non-stunted children $(p<0.041)$. Thus, it was likely that the small size of a rice field is an indication of food insecurity and is a cause of stunting among children under five. According to data from the Ministry of Health (2012), being raised in a family belonging to the poorest quintile in Indonesia had a 1.79 times risk of being stunted compared to the richest quintile. Higher risk of being stunted among poor families was also reported in the studies of Black et al. (2013) and Hong et al. (2006).

Correlation between lack of agricultural diversity (crops and livestock) and stunting among children in the study area could not be proved to be due to the domination of rice cultivation and production. Although the national government has tried to promote crop diversification, rice as a staple food still dominates the habitual Indonesian diet (Jati et al. 2012) and there is slow progress in shifting to the cultivation and consumption of alternative staple foods. Part of the reason for this is that government support for agricultural inputs (e.g. fertilizer and seed) and promotion of increased rice production is still concentrated in the rice buffer area. Prioritizing rice cultivation is also considered to be the best option by farmers in the study area because of market opportunities and farmers' experiences in producing rice. This is especially so if farm capital is a major constraint, as found by Siregar and Suryadi (2006). Thus intensive agriculture extension and continuous promotion and mentoring of crop diversification will be required to change the mindset of Indonesian farmers. Moreover, based on indepth interviews of farmers and heads of villages, planting rice enabled them and their families to secure household food stock at least until the next planting season.

Although chicken rearing is normally extensive among the Javanese, during the survey period only $3.6 \%$ of the households raised them. Besides own consumption, prior to data 
collection many of the respondents sold chickens to generate family income during the lean season, or exchanged them for other foods, e.g. vegetables, rice, and tofu/tempe.

Hoddinott (2012) and Fan and Brzeska (2012) discussed the effects of underlying factors in nutritional outcomes (UNICEF 1998) and their link to agriculture, especially choices and expenditure on a healthy and varied diet, as well as health care costs, which could result in a better nutritional status. Besides inadequate food intake, chronic infectious diseases also cause stunting in children. These two problems are aggravated by an unfavourable living environment and lack of health services (Gross et al. 1996). Particularly in the rice cultivation environment, they are correlated with several infectious diseases such as malaria, diarrhea and worm infestation. Proper water management of rice fields is one way of controlling vector-borne diseases (Roger and Joulian 1998) and providing private toilets and hand washing facilities reduce the incidence of infectious diseases spread by the fecal-oral route (Humphrey 2009). During the period of data collection in Demak, public health insurance (so-called Social Security Agency) for the whole Indonesian population had not been introduced. Private health insurance was usually paid for on a yearly basis, or personal health services and medication expenses were paid for when required. Therefore, health care costs could be an underlying factor in childhood stunting. Improvement of health and environmental conditions would be likely to result in better HAZscores among the children of Demak Rgency.

\section{Conclusions and recommendations}

Even though Demak Regency is an area of high rice production, child malnutrition, defined by HAZ-score below -2SD, was still high. In our study, stunted children were significantly older, thinner and smaller than non-stunted ones. They also belonged to families who had significantly smaller rice fields and produced rice solely or mostly for own consumption as compared to the non-stunted group. No significant difference was found between stunted and non-stunted children with respect to cultivation and livestock production factors in their households. The agricultural diversity assessed in this study was not significantly linked to stunting among children due to the superiority of rice cultivation in farmer's experience, government support for it, its potential market and utilization. Promotion of more diverse and nutritious crops, including alternative staple foods should be continued in order to guarantee greater dietary diversity.

The low yearly brutto revenue of the farmers was likely to be the main limitation for families in the study area for obtaining good access to food and health services, but income insecurity was not the only reason.

Yearly expenditure for improving family health and environmental condition was significantly higher among families with non-stunted than stunted children, suggesting that family decisions on types of purchases influenced the nutritional status of the children in the study area. Therefore, improvement of agriculture production and diversity should be accompanied by education on family expenditure.

Acknowledgement We would like to thank the Neys-van Hoogstraten Foundation for its financial support (IN252). Dr. R.C. Purwestri was also funded by the Federal Ministry of Education and Research within the project Humboldt reloaded (01PL11003) at the University of Hohenheim, Germany. We greatly appreciate the assistance of Daniel Pfaff, Mief Qur'anin Setyohadi, S. Gz, enumerators, voluntary workers, health workers (especially midwives and nutritionist), heads of villages, mothers and their children in the surveyed area, Demak Regency. We are also thankful to Prof. Hans-Peter Piepho and Dr. Jens Moehring for their statistical advice and Dr. Clark Capshaw for proof-reading this manuscript.

Authors' contributions RCP, LR, IRAPJ, HKB planned the study design. RCP, NN, IF implemented the study. LR and RCP performed the statistical analysis, interpreted the data and drafted the article. RCP and LR wrote the manuscript. All authors approved the final manuscript.

\section{Compliance with ethical standards}

Ethical approval and informed consent All procedures performed in studies involving human participants were in accordance with the ethical standards of the institutional and/or national research committee and with the 1964 Helsinki declaration and its later amendments or comparable ethical standards. The study protocol was approved by the Ethics Committee of the Faculty of Medicine, University of Brawijaya, Malang-Indonesia.

Informed consent was obtained from all individual participants included in the study; they volunteered to join the research study. The informants from in-depth interviews also gave their permission to be recorded.

Conflict of interest The authors have declared that no competing interests exist.

\section{References}

Black, R. E., Allen, L. H., Bhutta, Z. A., Caulfield, L. E., de Onis, M., Ezzati, M., \& Rivera, J. (2008). Maternal and child undernutrition: global and regional exposures and health consequences. The Lancet, 371(9608), 243-260. doi:10.1016/S0140-6736(07)61690-0.

Black, R. E., Victora, C. G., Walker, S. P., Bhutta, Z. A., Christian, P., de Onis, M., \& Uauy, R. (2013). Maternal and child undernutrition and overweight in low income and middle-income countries. The Lancet, 382(9890), 427-451. doi:10.1016/S0140-6736(13)60937-X.

Central Java Public Health Office (2012). Health Profile of Jawa Tengah 2012: Buku profil kesehatan provinsi Jawa Tengah tahun 2012. Retrieved from http://www.depkes.go. id/resources/download/profil/PROFIL_KES_PROVINSI_2012 /13_Profil_Kes.Prov.JawaTengah_2012.p̄df. Accessed 17 January $20 \overline{1} 6$.

Central Java Statistics Bureau (2014). Jawa Tengah in Figures 2014: Jawa Tengah dalam angka 2014. BPS Statistics of Jawa Tengah Province and Regional Development Planning. http://bappedajateng. 
info/publikasi/jawa-tengah-dalam-angka.html. Accessed 17 January 2016.

Dewey, K. G., \& Begum, K. (2011). Long-term consequences of stunting in early life. Maternal \& Child Nutrition, 7(3S), 5-18.

Fan, S., \& Brzeska, J. (2012). The nexus between agriculture and nutrition: do growth patterns and conditional factors matter? In S. Fan \& R. Pandya-Lorch (Eds.), Reshaping agriculture for nutrition and health (pp. 31-38). Washington, DC: Intl Food Policy Res Inst.

Fan, S., Pandya-Lorch, R., \& Fritschel, H. (2012). Overview. In S. Fan \& R. Pandya-Lorch (Eds.), Reshaping agriculture for nutrition and health. Washington, DC: Intl Food Policy Res Inst.

Grantham-McGregor, S., Cheung, Y. B., Cueto, S., Glewwe, P., Richter, L., Strupp, B., \& International Child Development Steering Group (2007). Developmental potential in the first 5 years for children in developing countries. The Lancet, 369(9555), 60-70 Retrieved from http://ac.els-cdn.com/S $0140673607600324 / 1$-s 2.0 S0140673607600324-main.pdf? tid=2c183ee0-6c26-11e5-be7900000 aab0f6bandacdnat $=1444134871 \_578 \mathrm{dd} 4 \mathrm{a} 32128655$ eefd30345f07e2aff. Accessed 17 January 2016.

Gross, R., Schultink, W., \& Sastroamidjojo, S. (1996). Stunting as an indicator for health and wealth: an Indonesian application. Nutrition Research, 16(11), 1829-1837 Retrieved from http://ac. els-cdn.com/S0271531796002072/1-s2.0-S0271531796002072main.pdf?_tid=447f8a0c-681a-11e5-8437-00000aacb35 fandacdnat $=14436899535993 \mathrm{c} 42 \mathrm{c} 442 \mathrm{a} 37 \mathrm{a} 47 \mathrm{f} 8 \mathrm{c} 9 \mathrm{c} 9 \mathrm{e} 8 \mathrm{c} 5 \mathrm{fc} 843$. Accessed 17 January $201 \overline{6}$.

Haddad, L. J. (2000). A conceptual framework for assessing agriculturenutrition linkages. Food and Nutrition Bulletin, 21(4), 367-373 Retrieved from http://fnb.sagepub.com/content/21/4/367.full. pdf + html. Accessed 17 January 2016.

Hoddinott, J. (2012). Agriculture, health and nutrition: toward conceptualizing the linkages. In S. Fan \& R. Pandya-Lorch (Eds.), Reshaping agriculture for nutrition and health (pp. 13-20). Washington, DC: Intl Food Policy Res Inst.

Hong, R., Banta, J. E., \& Betancourt, J. A. (2006). Relationship between household wealth inequality and chronic childhood under-nutrition in Bangladesh. International Journal for Equity in Health, 5, 15. doi:10.1186/1475-9276-5-15.

Humphrey, J. H. (2009). Child undernutrition, tropical enteropathy, toilets, and handwashing. Lancet, 374(9694), 1032-1035. doi:10.1016 /S0140-6736(09)60950-8.

Jati, I. R., Vadivel, V., Nohr, D., \& Biesalski, H. K. (2012). Dietary formulation to overcome micronutrient deficiency status in Indonesia. Nutrition and Food Science, 42(5), 362-370 Retrieved from http://www.emeraldinsight.com/doi/full/10.1108 /00346651211266881. Accessed 17 January 2016.

Kennedy, E. T., \& Bouis, H. E. (1993). Linkages between agriculture and nutrition: implications for policy and research. Washington, D.C.: International Food Policy Research Institute Retrieved from http://ageconsearch.umn.edu/bitstream/42929/2/Linkages\%20 between $\% 20$ agriculture $\% 20$ and $\% 20$ nutrition.pdf. Accessed 17 January 2016.

Kumar, N., Harris, J., \& Rawat, R. (2015). If they grow it, will they eat and grow? Evidence from Zambia on agricultural diversity and child undernutrition. The Journal of Development Studies, 51(8), 1060-1077.

Lwanga, S. K., \& Lemeshow, S. (1991). Sample size determination in health studies. A practical manual. Geneva: WHO.

M'Kaibi, F. K., Steyn, N. P., Ochola, S. A., \& Du Plessis, L. (2016). The relationship between agricultural biodiversity, dietary diversity, household food security, and stunting of children in rural Kenya. Food Science \& Nutrition. doi:10.1002/fsn3.387/epdf.
Martorell, R. (1999). The nature of child malnutrition and its long-term implications. Food and Nutrition Bulletin, 20(3), 288-292.

Martorell, R., Horta, B. L., Adair, L. S., Stein, A. D., Richter, L., Fall, C. H., et al. (2010a). Weight gain in the first two years of life is an important predictor of schooling outcomes in pooled analyses from five birth cohorts from low- and middle-income countries. Journal of Nutrition, 140(2), 348-354. doi:10.3945/jn.109.112300.

Martorell, R., Melgar, P., Maluccio, J. A., Stein, A. D., \& Rivera, J. A. (2010b). The nutrition intervention improved adult human capital and economic productivity. Journal of Nutrition, 140(2), 411-414. doi:10.3945/jn.109.114504.

Ministry of Health (2012). Riset Kesehatan Dasar: Riskesdas 2010. Jakarta, Indonesia. Retrieved from http://www.riskesdas.litbang. depkes.go.id/download/TabelRiskesdas2010.pdf. Accessed 17 January 2016.

Ministry of Health (2013). 2013: Riset kesehatan dasar: Riskesdas 2013. Jakarta Indonesia. Retrieved from http://www.depkes.go. $\mathrm{id} /$ resources/download/general/Hasil\%20Riskesdas\%202013.pdf. Accessed 17 January 2016.

Purwestri, R. C., Scherbaum, V., Inayati, D. A., Wirawan, N. N., Suryantan, J., Bloem, M. A., Pangaribuan, R. V., Stuetz, W., Hoffmann, V., Qaim, M., Biesalski, H. K., \& Bellows, A. C. (2013). Impact of daily versus weekly supply of locally produced ready-to-use food on growth of moderately wasted children on Nias Island, Indonesia. ISRN Nutrition, 2013 ，10. doi:10.5402/2013 /412145.Article ID 412145

Roger, P.A., Joulian C. (1998). Environmental impacts of wetland rice cultivation. In Rice quality: a pluridisciplinary approach. Cahiers Options Méditerranéennes, 24 (3), p. 15 ISSN 1022-1379. Retrieved from $\mathrm{http} / /$ horizon.documentation.ird.fr/exl-doc/pleins_textes/pleins textes_6/b_fdi_49-50/010018096.pdf. Accessed 29 April 2016.

Rosado, J. L. (1999). Separate and joint effects of micronutrient deficiencies on linear growth. Journal of Nutrition, 129, 531S-533S.

Semba, R. D., de Pee, S., Sun, K., Sari, M., Akhter, N., \& Bloem, M. W. (2008). Effect of parental formal education on risk of child stunting in Indonesia and Bangladesh: a cross-sectional study. The Lancet, 371(9609), 322-328 Retrieved from http://ac.els-cdn. com/S0140673608601695/1-s2.0-S0140673608601695-main. pdf?_tid $=6860 \mathrm{c} 616-65 \mathrm{fe}-11 \mathrm{e} 5-898 \mathrm{c}-00000 \mathrm{aab} 0 \mathrm{f0} 1$ andacdnat $=1443458085 \quad 81 \mathrm{e} 59 \mathrm{cbe} 33 \mathrm{a} 8 \mathrm{f} 784 \mathrm{ff5} 819 \mathrm{cf} 770290 \mathrm{~b} 4$. Accessed 17 January $201 \overline{6}$.

Seth, V., Garg, A., \& Vir, S. C. (2011). Complementary feeding of infants and young children. In S. C. Vir (Ed.), Public health nutrition in developing countries (pp. 223-251). New Delhi: Woodhead Publishing India.

Siregar M., \& Suryadi M. (2006). Changes in food crop diversification in Indonesia. Bogor: Indonesian Center for Agricultural Socio Economic Research and Development. Retrieved from http://pse.litbang. pertanian.go.id/eng/pdffiles/Mono27-3.pdf. Accessed 10 July 2016.

Stephensen, C. B. (1999). Burden of infection on growth failure. Journal of Nutrition, $129,534 \mathrm{~S}-538 \mathrm{~S}$.

UNICEF. (1998). The state of the world's children report. New York: UNICEF. Retrieved from http://www.unicef. org/sowc/archive/ENGLISH/The\%20State\%20of\%20the\%20 World's\%20Children\%201998.pdf. Accessed 17 January 2016.

Victora, C. G., Fall, C., Hallal, P. C., Martorell, R., Richter, L., \& Sachdev, H. S. (2008). Maternal and child undernutrition 2. Maternal and child undernutrition: consequences for adult health and human capital. The Lancet, 371(9608), 340-356.

Victora, C. G., Fall, C., Hallal, P. C., Blössner, M., \& Shrimpton, R. (2010). Worldwide timing of growth faltering: revisiting implications for interventions. Pediatrics, 125(3), e473. 


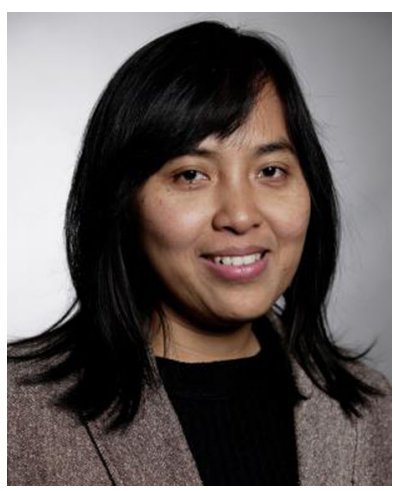

Dr. Ratna Chrismiari Purwestri obtained her Doctoral degree in Agricultural Sciences in 2011 from the Institute of Social Sciences in Agriculture, Department of Gender and Food, University of Hohenheim, Stuttgart-Germany. Her PhD thesis is entitled: Supplementary feeding and cost analysis of locally produced Ready-to-Use Food (RUF) for moderately and mildly wasted children in Nias Island, Indonesia: daily and weekly programs. She was awarded a Master of Science in Nutrition in 2001 from the Faculty of Medicine, Study program Community Nutrition, University of Indonesia, Jakarta-Indonesia. Her BSc in Animal Husbandry was acquired in 1995 from the Gadjah Mada University, Yogyakarta-Indonesia. She received a scholarship from South East Asia Minister of Education Organization-Tropical Medicine (SEAMEO-TROPMED) network-DAAD during her Masters degree study period and received a DAAD $\mathrm{PhD}$ scholarship for continuing her study in Germany. Her work as a community nutritionist began after her MSc graduation, when she was employed by the SEAMEO-TROPMED Regional Center for Community Nutrition (RCCN), University of Indonesia. She has written and co-written several published papers in international journals. Currently she is a PostDoc researcher at the University of Hohenheim, Germany and a member of the research staff at the Faculty of Medicine, Nutrition Department, University of Brawijaya, Malang.

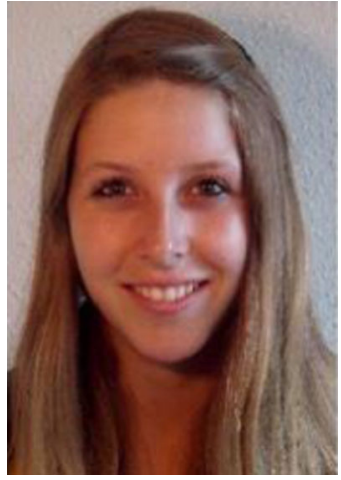

Loretta Renz, MSc received her Bachelor degree in Nutrition science in 2013, and then continued on to her Masters degree in organic agriculture and food systems (2013-2015) at the University of Hohenheim. She was a participant in a one-year studentexchange (2008-2009) during her bachelor study at the University of Diponegoro, Semarang, Indonesia. Her background in agriculture and nutrition has enabled her to participate actively in this project. The analysis in her masters thesis entitled: "Association between agricultural factors and nutritional status of under-five children living in Demak Regency, Central Java, Indonesia" was the preliminary analysis for this manuscript. Besides her educational activities, she has been involved with social work for disadvantaged people.

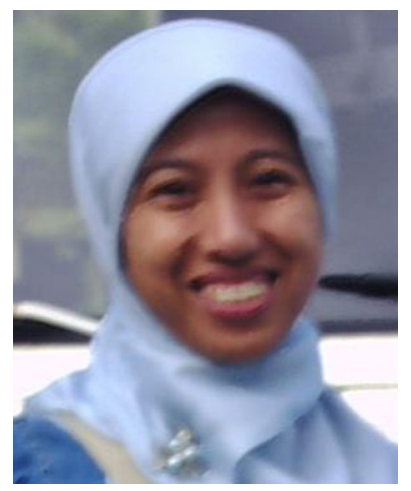

Nia Novita Wirawan, MSc is currently a member of academic staff at the Nutrition Department, Faculty of Medicine, University of B rawijaya, Malang, Indonesia. She teaches several subjects in community nutrition-related subjects, e.g. Nutritional assessment, Intervention Monitoring and evaluation of Communitybased programs. She also actively carries out nutrition-related projects in different regions in Indonesia. In 1997 she graduated from the Nutrition academy, Malang, received her bachelor degree from the Faculty of Food Technology, University of Indonesia, Malang (2000), and most recently she obtained her Masters degree in Nutrition science at the Community Nutrition study program, Faculty of Medicine, University of Indonesia, Jakarta, which was organized by the SEAMEO-TROPMED RCCN-University of Indonesia.

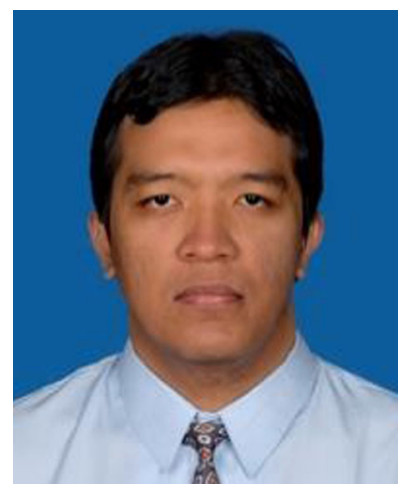

Ignasius Radix A. P. Jati received his doctoral degree (Dr.rer.nat) from the University of Hohenheim, Germany in 2014. He did his doctoral work at the Institute of Biological Chemistry and Nutrition funded by a scholarship from the Food Security Center, University of Hohenheim and supported by DAAD and BMZ. His research topic was an integrated approach to enhance food and nutrition security in Indonesia. He obtained his MSc from Gadjah Mada University, Indonesia in 2007 through an ASEA UNINET scholarship. Recently, he worked as a lecturer and researcher in the Department of Food Technology and Human Nutrition, Widya Mandala Catholic University Surabaya, Indonesia. His research areas are on vitamin A, micronutrients, nutrient density, dietary habit, and bioactive compounds of plants. He has published a number of articles in international journals as well as book chapters. 


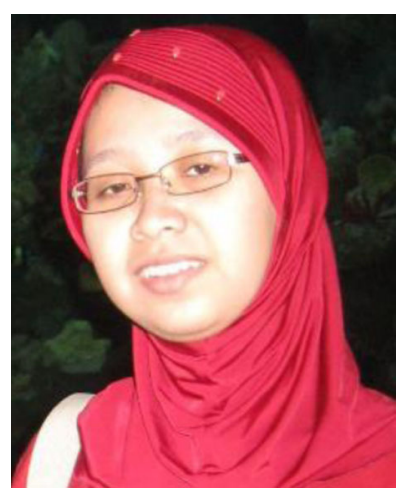

Ilmia Fahmi , BSc graduated from the Nutrition Department, Faculty of Medicine, University of Brawijaya, Malang in 2010. Upon graduation she worked at the same Department, assisting and working in several community nutrition-related research projects in several regions in Indonesia and East Timor. Starting in 2015 she continued her studies with the Community Nutrition study program at the Faculty of Medicine, University of Indonesia, Jakarta.

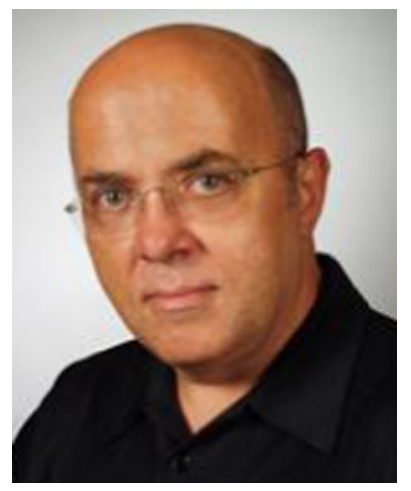

Hans Konrad Biesalski , MD, PhD is currently head of the Department of Biological Chemistry and Nutrition at the University of Hohenheim in Stuttgart, Germany. After his studies of Physics at the University of Mainz (19711974) and his appointment as Research Assistant at the Department of Physiology, Division of Physics, in 1979, he graduated in 1981 with an MD thesis about "Progressive Hearing Disorders in childhood". After several years' activity as Assistant Professor, he obtained his habilitation in 1987 with the thesis "Vitamin A and Inner Ear. Development and Application of Biochemical and Electrophysiological Studies”. In 1993, he was appointed Associated Professor, then full C4-Professor at the Department of Biological Chemistry and Nutrition at the University of Hohenheim. Prof. Dr. Biesalski has 25 years of experience in research on retinoids and their actions on cellular growth and differentiation, vitamin A and human health, especially lung diseases. Since 1993, his research activities have concentrated on antioxidants, on reactive oxygen species and their role in human nutrition. He is holder of several patents and founded a biotech company (BioTeSys $\mathrm{GmbH}$ ) in Esslingen, Germany, in 2000, which develops cell and organ culture models to test biological compounds. He also carries out clinical studies. Prof. Dr. Biesalski is a member of the executive boards and scientific advisory boards of the most important German health societies and academies and is a member of the Scientific Advisory Board of the US Pharmacopoeia. He is also a board member of several scientific journals and a member of different international societies and vitamin consultative groups. He has been elected a fellow in the Institute for Advanced Study, Berlin. He has edited 7 books related to Nutritional Medicine, Clinical Nutrition and Ageing and has published numerous papers in the most prestigeous scientific journals, some of which he peer-reviews as well. He has chaired several international conferences (amongst others, the WHO Conference on Nutrition and Cancer in 1997 and the First Congress Nutrition Teams) and has given many invited lectures at congresses and symposia. 